\section{Diallel analysis in cowpea aiming at selection for extra-earliness}

\author{
Rosana Mendes de Moura Oliveira ${ }^{1^{*}}$, Francisco Rodrigues \\ Freire Filho ${ }^{2}$, Valdenir Queiroz Ribeiro ${ }^{3}$, Ângela Celis de Almei- \\ da Lopes ${ }^{1}$, Karla Annielle da Silva Bernardo ${ }^{1}$ and Akemi Suzuki \\ Cruzio $^{1}$
}

\begin{abstract}
In Brazil, the production of cowpea is concentrated in the Northeast and North; however, in recent years, its cultivation has expanded to the Cerrado biome of the Brazilian Midwest region, where it is incorporated into production arrangements in the form of off-season. In this work, it was carried out a study on the extra-earliness in cowpea in order to select parents and crosses with cycle shorter than 60 days. A test with an $F_{2}$ generation of a complete diallel cross involving five parents and ten crosses was carried out in a complete randomized block design with six replications. The parents IT82D-889 and AU94-MOB-816 stood out for extra-earliness flowering, while IT82D-60 and IT82D-889 stood out for extra-earliness maturity. The crosses IT82D-60 x AU94-MOB-816 and IT82D-60 x IT82D-889 were more promising in extra-earliness flowering, while IT82D-60 x IT82D-889 and IT82D-60 x MNC04-789B-119-2-3-1 were more promising for extra-earliness maturity.
\end{abstract}

Key words: Vigna unguiculata, combining ability, flowering and maturity.

\section{INTRODUCTION}

Cowpea (Vigna unguiculata (L.) Walp.) is an excellent protein source, and it presents all the essential amino acids, and is rich in carbohydrates, vitamins and minerals, besides having great fiber content and low fat content, constituting an important food component in several countries (Freire Filho et al. 2011).

It is grown by small and medium farmers in the North and Northeast of Brazil, and recently, it has been grown by large producers in these regions (Xavier et al. 2005). In the past years, its cultivation has expanded to the Cerrado biome of the Brazilian Midwest, where it is incorporated into production arrangements in the form of off-season, following soybeans, or rice and corn (Freire Filho et al. 2011). In these arrangements, cowpea is grown after the mid-rainy season, when there is no expectation of rainfall that would allow the cultivation of cornas second-crop. In this context, there is a short planting window for farmers interested in growing cowpea, to which cultivars of early and medium-early cycles fit perfectly, since their cycles last from 60 to 80 days. Thus, an alternative to enlarge the planting window for cowpea would be the use of extra-early cultivars with cycles shorter than 60 days.

Silva et al. (2007) mention that the main way to evaluate earliness is through the time between the sowing and the emergence of the first flowers. However,
Crop Breeding and Applied Biotechnology 16: 167-173, 2016 Brazilian Society of Plant Breeding. Printed in Brazil http://dx.doi.org/10.1590/1984$70332016 v 16 n 3 a 26$
E-mail: rosanamendes.moura@gmail.com

Received: 10 July 2014 Accepted: 4 January 2016

${ }^{1}$ Universidade Federal do Piauí, Campus da Socopo, 64.049-550, Teresina, PI, Brazil

${ }^{2}$ Embrapa Amazônia Oriental, Travessa Doutor Enéas Pinheiro, s/n, Bairro Marco, 66.095100, Belém, PA, Brazil

${ }^{3}$ Embrapa Meio-Norte, Av. Duque de Caxias, no 5.650, Bairro Buenos Aires, 64.006-220, Teresina, PI, Brazil 
Ribeiro et al. (2004) reported that early flowering genotypes do not necessarily present low cycle. According to Singh (1986), earliness is an essential factor in the process of adaptation of a culture to any agro-climatic zone, especially in the semiarid region, which may be associated with some stress factors that occur at the end of the development period. Adeyanju and Ishiyaku (2007) reported that earliness is an important agronomic trait, and it is important for cowpea in areas with relatively short rainfall cycle. Padi (2007) mentions that grain size and earliness are essential traits for the adoption of cowpea cultivars in the savannas of West Africa.

Based on maturity, Freire Filho et al. (2005) divided cowpea cycle into: extra-early cycle - maturity at up to 60 days after sowing; early cycle - maturity between 61 and 70 days after sowing; medium-early cycle - maturity between 71 and 80 days after sowing; medium-late cycle - maturity between 81 and 90 days after sowing; and late cycle - maturity from 91 days after sowing.

The knowledge of the potential combinations of genotypes that can be used in crosses serves as the basis for the identification of the parents and the crosses that will result in superior segregating populations. Among the methodologies used to evaluate parents and their combinations, diallels should be highlighted. The diallel scheme has been defined as a method, in which a group of homozygous lines is selected, which are crossed in pairs, providing a maximum of $p^{2}$ combinations (Hayman 1954).

Sprague e Tatum (1942) established and defined the terms of general combining ability (GCA) and specific combining ability (SCA), being GCA the average behavior of a parent in a series of hybrid combinations, and is associated with allele additive effects. On the other hand, SCA is used to denote hybrid combinations that are relatively superior or inferior than what is expected based on GCA (Cruz and Vencovsky 1989). Griffing (1956) proposed a new method of diallel analysis, in which GCA and the SCA are also estimated. This method is the most used due to its generality and application easiness.

This study aimed at evaluating parents regarding extra earliness and selecting potential crosses to produce extra early lines with cycle shorter than 60 days.

\section{MATERIAL AND METHODS}

\section{Parents and diallel cross}

As parents, it was used the lines IT82D-889 and IT82D-60, from the International Institute of Tropical Agriculture (IITA), Nigeria; AU94-MOB-816, from Auburn University, USA; and MNC04-789B-119-2-3-1 and MNC05-820B-240, from Embrapa Mid-North, Brazil. Seeds were provided by the Cowpea Breeding Program of Embrapa Mid-North, Teresina, PI (Table 1).

For the crosses, the five parents ( $\mathrm{n}$ ) were sown in a screen house, in order to avoid the occurrence of natural crosses by insects, and were crossed among each other in a complete diallel scheme excluding reciprocal $\left(\frac{(n-1) n}{2}\right)$, resulting in ten crosses. In the crosses, it was used the method presented by Rachie et al. (1975) and Zary and Muller Junior (1982).

\section{Experimental design}

The experiment was carried out at the experimental field of Embrapa Mid-North, Teresina, PI, in a randomized block design, with six replications, and 15 treatments, corresponding to five parents and ten $\mathrm{F}_{2}$ crosses. The experimental plot

Table 1. Identification, origin, grain color, and number of days to flowering and maturity of five parents

\begin{tabular}{|c|c|c|c|c|}
\hline Parents & Origin & Grain Color & $\mathrm{NDF}^{3}$ & NDM $^{4}$ \\
\hline IT82D-889 & IITA, Nigéria ${ }^{1}$ & Red & 38.19 & 54.32 \\
\hline AU94-MOB-816 & Auburn University, USA & Red/White & 37.82 & 55.06 \\
\hline IT82D-60 & IITA, Nigeria & Black eye & 38.32 & 54.61 \\
\hline MNC04-789B-119-2-3-1 & Embrapa, Brazil $\left.\right|^{2}$ & Black eye & 39.82 & 55.06 \\
\hline MNC05-820B-240 & Embrapa, Brazil & Black eye & 39.82 & 56.10 \\
\hline
\end{tabular}

${ }^{1}$ International Institute of Tropical Agriculture

2 Brazilian Agricultural Research Corporation

${ }^{3}$ Number of days to flowering

${ }^{4}$ Number of days to maturity. 
consisted of four $5.0 \mathrm{~m}$ rows, spaced $0.60 \mathrm{~m}$ between rows, and $0.25 \mathrm{~m}$ between plants within the row. Approximately 20 days after sowing, seven plants were labeled at random in the two central rows, corresponding to the useful area of the plot for the data collection, except for weight of 100 grains and grain yield, which were measured from the entire plot. The following traits were evaluated: number of days to flowering (NDF): number of days between sowing and the emergence of the first flower; number of days to maturity (NDM): number of days between sowing and the emergence of the first pod with color change, dry beans, ready for harvesting; plant height (PH): measured from the base of the plant to the top of the main branch, which was evaluated from the maturity of pods; pod length (PL): length of a pod randomly taken from each plant; number of grains per pod (NGP): number of grains obtained in the same pod used to measure the length; weight of 100 grains (W100G): weight of 100 grains sample randomly taken from the plot yield; and plot yield(PY): dry grains, obtained after harvesting all the plants of the plot, including plants individually harvested.

\section{Statistical analysis}

Initially, it was carried out analysis of variance in a complete randomized block for each trait. After that, by using the mean square error of the analyses of variance, it was carried out the analysis according to Method 2, model B of Griffing (1956), to estimate the effects of General Combining Ability (GCA) of the parent, and the Specific Combination Ability (SCA) of the cross, from a set of $p$ parents and of the resulting generations, according to the statistical model:

$Y_{i j}=m+g_{i}+g_{j}+s_{i j}+e_{i j}$

in which,

$Y_{i j}$ : is the mean value observed during the hybrid combination $(i \neq j)$ or the parent combination $(i=j)$;

$m$ : is the general mean;

$g_{i}$ and $g_{j}$ : are the effects of general combining ability of the $\mathrm{i}$-th and $\mathrm{j}$-th parent, respectively;

$s_{i j}:$ is the effect of specific combining ability for crosses between parents $i$ and $j$;

$e_{i j}:$ is the experimental error.

The mean of NDF, NDM and NGP were transformed into $\sqrt{\mathrm{x}}$ in order to obtain homoscedasticity of variances and error adjustment to an approximately normal distribution. The means of each trait were used for combining ability analysis through the unfolding of the treatment effect on GCA and SCA effects. The significance of the estimates of GCA and SCA effects were verified by the bilateral Student $t$ test. It was carried out clustering analysis by the Scott-Knot test at $5 \%$ probability. Coefficient of variation was used for the evaluation of experimental precision. In all the analyses, it was used the Genes software (Cruz 2006).

\section{RESULTS AND DISCUSSION}

The effect of GCA was significant $(\mathrm{P}<0.01)$ for all traits, except for $\mathrm{PH}$ and $\mathrm{PY}$, evidencing the importance of additive effect in inheritance. In this case, genotypes with greater effect for these traits had more favorable genes for cycle reduction. For SCA, in traits with significant effect $(P<0.01)$, dominance proved to be relevant, and there may be complementarity between some parents that could generate superior lines (Table 2).

Table 2 also shows the coefficients of experimental variation. Most traits presented low values, ranging from 0.85 to 17.23\% (Pimentel Gomes 2000). NDM had the lowest coefficient (0.85\%), and PY had the highest coefficient (17.23\%). The high coefficient of experimental variation obtained for PY can be explained by the fact that it is a quantitative trait, which is strongly influenced by the environment, and which can increase the estimate of the mean squares of the estimated errors. However, these values are expected, and evidence the good experimental precision of the study.

Table 3 shows GCA estimates. Lal et al. (1975) stated that for NDF it is more desirable that the parent presents negative estimate. The negative values obtained in parents for NDF and NDM indicate that a combination of these parents would result in a reduction in the expression of these traits. Since the main objective of the work is selection for extra-earliness, parents with GCA of high magnitude, but negative for NDF and NDM are the most important for reducing the expression of these traits. Thus, the parents AU94-MOB-816, IT82D-889 and IT82D-60 presented GCA 
Table 2. Summary of the analysis of variance of traits related to earliness and grain yield in cowpea (Vigna unguiculata (L.) Walp.)

\begin{tabular}{|c|c|c|c|c|c|c|c|c|}
\hline \multirow[b]{2}{*}{ SV } & \multirow[b]{2}{*}{ df } & \multicolumn{7}{|c|}{ Mean square } \\
\hline & & $\begin{array}{l}\text { NDF } \\
\text { (day) }\end{array}$ & $\begin{array}{l}\text { NDM } \\
\text { (day) }\end{array}$ & $\begin{array}{c}\mathrm{PH} \\
(\mathrm{cm})\end{array}$ & $\begin{array}{c}\mathrm{PL} \\
(\mathrm{cm})\end{array}$ & NGP & $\begin{array}{l}\text { W100G } \\
\text { (g) }\end{array}$ & $\begin{array}{c}\text { PY } \\
\left(\mathrm{kg} \mathrm{ha}^{-1}\right) \\
\end{array}$ \\
\hline Treatments & 14 & $0.053^{* *}$ & $0.028^{* *}$ & $75.104^{* *}$ & $12.451^{* *}$ & $0.415^{* *}$ & $49.291^{* *}$ & $103885.977^{* *}$ \\
\hline SCA & 10 & 0.019 & $0.021^{* *}$ & $90.353^{* *}$ & $2.165^{* *}$ & $0.070^{* *}$ & $9.363^{* *}$ & $132237.922^{* *}$ \\
\hline Error & 70 & 0.017 & 0.004 & 19.499 & 0.410 & 0.015 & 2.175 & 14853.896 \\
\hline
\end{tabular}

${ }^{* *}$ Significant at $1 \%$ probability

Table 3. Estimates of the effects of general combining ability (GCA) for traits related to earliness and grain yield in cowpea (Vigna unguiculata (L.) Walp.)

\begin{tabular}{|c|c|c|c|c|c|c|c|}
\hline \multirow[b]{2}{*}{ Parents } & \multicolumn{7}{|c|}{ General Combining Ability (GCA) } \\
\hline & $\begin{array}{l}\text { NDF } \\
\text { (day) }\end{array}$ & $\begin{array}{l}\text { NDM } \\
\text { (day) }\end{array}$ & $\begin{array}{l}\mathrm{PH} \\
(\mathrm{cm})\end{array}$ & $\begin{array}{c}\mathrm{PL} \\
(\mathrm{cm})\end{array}$ & NGP & $\begin{array}{l}\text { W100G } \\
(\mathrm{g})\end{array}$ & $\begin{array}{c}\text { PY } \\
\left(\mathrm{kg} \mathrm{ha}^{-1}\right)\end{array}$ \\
\hline IT82D-889 & $-0.046^{* *}$ & $-0.028^{* *}$ & -0.862 & $1.611^{* *}$ & $0.142^{* *}$ & $-2.519^{* *}$ & $-21.389^{* *}$ \\
\hline IT82D-60 & -0.025 & $-0.029^{* *}$ & 0.864 & $-0.519^{* *}$ & $-0.036^{* *}$ & 0.089 & -33.401 \\
\hline MNC04-789B-119-2-3-1 & $0.064^{* *}$ & $0.022^{* *}$ & -0.953 & 0.095 & $-0.045^{* *}$ & $0.670^{* *}$ & $1.550^{* *}$ \\
\hline
\end{tabular}

$*, * *$ significant $\mathrm{p}<0.05$, and significant $\mathrm{p}<0.01$, respectively, by the $t$ test.

estimates more favorable for the reduction of NDF, indicating that they are the most promising for the reduction of the trait expression. These same parents also stood up for NDM, with negative values of GCA, and therefore were the most recommended for breeding programs for selection for extra-earliness in cowpea. All parents were significant for NDF, except for IT82D-60. For NDM, only AU94-MOB-816 presented no significance.

The values of GCA estimates for PH ranged from -0.953 (MNC04-789B-119-2-3-1) to 1.053 (AU94-MOB-816). The parents AU94-MOB-816 and IT82D-60 stood out, showing great potential for improving the expression of this trait. GCA estimates for PL ranged from -0.760 to 1.611 . The most favorable estimates for this trait were obtained by IT82D-889 and MNC04-789B-119-2-3-1, with values of 1.611and 0.095, respectively. Among these parents, IT82D-889 stood out for presenting GCA estimate superior to the other parents. All parents were significant for this trait, except for MNC04789B-119-2-3-1. For NGP, all parents showed significant effects. The highest estimates were 0.188 and 0.142 for AU94MOB-816 and IT82D-889, respectively. The parent MNC05-820B-240 had the highest GCA estimate for W100G. For PY, all parents showed significant effects, except for IT82D-60. The parents AU94-MOB-816 and MNC05-820B-240 showed the highest GCA estimate for PY, proving to be promising for the use in programs aimed at yield increase. According to Lorencetti et al. (2005), the choice of parents for the formation of segregating populations is crucial for the success of a breeding program, and the combining ability with the presence of complementary genes is responsible for the success of the crosses.

Table 4 presents SCA estimates. There was no statistically difference for NDF, showing that all crosses behaved similarly. However, IT82D-60 x AU94-MOB-816, IT82D-889 x AU94-MOB-816 and IT82D-60 x IT82D-889 should be highlighted for presenting negative estimates for this trait. It was also observed that the three genotypes that participated in these crosses presented the best GCA estimates for the trait in question, which is in accordance with Cruz et al. (2004), who stated that a good cross must present significant SCA estimate, at the time that their parents require high GCA estimates for the trait under study.

For NDM, IT82D-60 x IT82D-889 and IT82D-60 x AU94-MOB-816 presented significant effect. The most promising crosses for NDM were IT82D-60 x AU94-MOB-816, IT82D-60 x IT82D-889 and IT82D-60 x MNC04-789B-119-2-3-1. The first two combinations also stood out regarding NDF estimates, proving to be potential crosses to produce extra early descendants. In PH, the cross IT82D-60 x AU94-MOB-816 stood out for presenting significant effect and also for showing high SCA estimate. For PL, six crosses had positive estimates, highlighting the crosses MNC05-820B-240 x AU94-MOB-816, and AU94-MOB-816 x MNC04-789B-119-2-3-1 with high estimates. The crosses MNC05-820B-240 x IT82D-60, AU94- 
Table 4. Estimates of the effects of specific combining ability (SCA) for traits related to earliness and grain yield in cowpea (Vigna unguiculata (L.) Walp.)

\begin{tabular}{|c|c|c|c|c|c|c|c|}
\hline \multirow[b]{2}{*}{ Crosses } & \multicolumn{7}{|c|}{ Specific Combining Ability (SCA) } \\
\hline & $\begin{array}{l}\text { NDF } \\
\text { (day) }\end{array}$ & $\begin{array}{l}\text { NDM } \\
\text { (day) }\end{array}$ & $\begin{array}{l}\mathrm{PH} \\
(\mathrm{cm})\end{array}$ & $\begin{array}{c}\mathrm{PL} \\
(\mathrm{cm})\end{array}$ & NGP & $\begin{array}{c}\text { W100G } \\
(\mathrm{g})\end{array}$ & $\begin{array}{c}\text { PY } \\
\left(\mathrm{kg} \mathrm{ha}^{-1}\right)\end{array}$ \\
\hline IT82D-889 x AU94-MOB-816 & -0.055 & -0.016 & 2.406 & $0.531^{* *}$ & $-0.183^{* *}$ & $2.526^{* *}$ & $-124.549^{* *}$ \\
\hline IT82D-889 x MNC04-789B-119-2-3-1 & 0.020 & 0.039 & 2.590 & $-0.481^{* *}$ & -0.001 & $-1.213^{*}$ & -15.780 \\
\hline MNC05-820B-240 x IT82D-889 & -0.014 & -0.028 & 2.112 & -0.126 & -0.008 & -0.466 & 68.776 \\
\hline MNC05-820B-240 x AU94-MOB-816 & -0.036 & -0.001 & 0.430 & $1.078^{* *}$ & $0.109^{*}$ & -0.156 & 43.027 \\
\hline IT82D-60 x MNC04-789B-119-2-3-1 & 0.024 & -0.044 & 0.736 & 0.148 & -0.033 & $1.510^{* *}$ & 65.778 \\
\hline MNC05-820B-240 x IT82D-60 & -0.023 & -0.005 & -0.614 & 0.337 & $0.617^{* *}$ & $-1.068^{*}$ & $124.727^{* *}$ \\
\hline MNC05-820B-240 x MNC04-789B-119-2-3-1 & 0.046 & -0.005 & 1.366 & -0.110 & $-0.106^{*}$ & -0.489 & $-305.424^{* *}$ \\
\hline
\end{tabular}

$*$, ** Significant $\mathrm{p}<0.05$, and significant $\mathrm{p}<0.01$, respectively, by the $\mathrm{t}$ test.

MOB-816 x MNC04-789B-119-2-3-1, and MNC05-820B-240 x AU94-MOB-816 had the highest SCA estimates for NGP.

The cross IT82D-889 x AU94-MOB-816 was the most promising for W100G. However, both parents of this cross had negative GCA estimates for the same trait. This fact is evident since different genotypes may be more efficient if they are combined. Such result may have occurred due to the high complementarity between the parents, with respect to genes related to the trait. According to Silva et al. (2004), not always the parent with high GCA estimates generate the best cross when combined with each other. The cross MNC05-820B-240 x MNC04-789B-119-2-3-1 presented one of the lowest SCA estimates for W100G (-0.489). However, these same parents had the highest GCA estimates for the trait in question. Result shows the low complementarity between the parents for this trait.

Grain yield is one of the most important traits for breeders. Therefore, the best crosses for the trait are selected, i.e., those with high SCA estimates, involving parents with high GCA (Oliveira Júnior et al. 1999). Thus, the cross AU94MOB-816 x MNC04-789B-119-2-3-1 presented genetic potential superior to the others, since the parents presented the highest GCA estimates for PY. The crosses MNC05-820B-240 x IT82D-60 and IT82D-60 x IT82D-889 also stood out for this trait, with high estimates.

According to the GCA and SCA estimates, the materials which showed the greatest potential for extra earliness selection were the parents IT82D-889, AU94-MOB-816 and IT82D-60, and the crosses IT82D-60 x AU94-MOB-816, IT82D-889 x AU94-MOB-816 and IT82D-60 x IT82D-889. According to SCA, the cross IT82D-60 x AU94-MOB-816 is the most recommended for extra earliness selection, since it showed significant estimates for NDF and NDM. For PY, this cross presented negative estimate, which is not satisfactory. However, when it is taken into account both extra earliness and yield, the most recommended cross is IT82D-889 x IT82D-60.

Table 5 shows the means and the result of the clustering by the Scott-Knott test. Genotypes were distributed into two to five groups. For NDF, the test clustered the genotypes in only two clusters. "Cluster A", which allocates the genotypes with the best mean, had only one parent (AU94-MOB-816). NDF general mean was 38.19 days, which was below the value found by Bertini et al. (2009), with mean of 47.17 days. For NDM, the crosses IT82D-889 x MNC05-820B-240 and AU94-MOB-816 x MNC05-820B-240 stood out and presented the best means, 52.85 days and 52.14 days, respectively. These two crosses also stood out for NDF. The general mean for NDM was 54.46 days, which was below the value obtained by Santos et al. (2012).

In cowpea, the ideal height of the plant for mechanical harvesting has not been determined yet. Simone et al. (1992), referring to the ideotype of common bean (Phaseolus vulgaris L.) upright cultivar for mechanical harvesting, suggest that the height is between 50 to $55 \mathrm{~cm}$. PH general mean obtained in the experiment was $28.69 \mathrm{~cm}$, well below the suggested value. The cross AU94-MOB-816 x MNC05-820B-240 showed the best mean for this trait $(37.83 \mathrm{~cm})$. The cross IT82D-889 x IT82D-60 stood out for PL, with mean of $19.62 \mathrm{~cm}$, which had general mean of $15.98 \mathrm{~cm}$, higher than that obtained by Teixeira et al. (2007). For NGP, three crosses obtained the best means and were allocated in "Cluster 
Table 5. Means of the traits: number of days to flowering (NDF), number of days to maturity (NDM), plant height (PH), pod length $(\mathrm{PL})$, number grains per pod (NGP), weight of 100 grains (W100G), and plot yield (PY) of cowpea

\begin{tabular}{|c|c|c|c|c|c|c|c|}
\hline Genotypes & $\begin{array}{l}\text { NDF }^{1} \\
\text { (day) }\end{array}$ & $\begin{array}{l}\text { NDM }^{1} \\
\text { (day) }\end{array}$ & $\begin{array}{c}\mathrm{PH} \\
(\mathrm{cm})\end{array}$ & $\begin{array}{c}\mathrm{PL} \\
(\mathrm{cm})\end{array}$ & NGP $^{1}$ & $\begin{array}{c}\text { W100G } \\
(\mathrm{g})\end{array}$ & $\begin{array}{c}\text { PY } \\
\left(\mathrm{kg} \mathrm{ha}^{-1}\right)\end{array}$ \\
\hline IT82D-60 & $38.32 \mathrm{~B}$ & $54.61 \mathrm{C}$ & $28.83 \mathrm{~B}$ & $15.33 \mathrm{C}$ & $8.47 \mathrm{C}$ & $19.67 \mathrm{~B}$ & $680.50 \mathrm{~B}$ \\
\hline AU94-MOB-816 & $37.82 \mathrm{~A}$ & $55.06 \mathrm{C}$ & $30.07 \mathrm{~B}$ & $15.83 \mathrm{C}$ & $10.18 \mathrm{~B}$ & $19.67 \mathrm{~B}$ & $669.67 \mathrm{~B}$ \\
\hline MNC04-789B-119-2-3-1 & $39.82 \mathrm{~B}$ & $55.5 \mathrm{C}$ & $29.00 \mathrm{~B}$ & $15.50 \mathrm{C}$ & $7.51 \mathrm{D}$ & $20.83 \mathrm{~B}$ & $351.17 \mathrm{D}$ \\
\hline AU94-MOB-816 x MNC05-820B-240 & $36.36 \mathrm{~A}$ & $52.14 \mathrm{~A}$ & $37.83 \mathrm{~A}$ & $14.67 \mathrm{D}$ & $11.15 \mathrm{~B}$ & $17.17 \mathrm{C}$ & $468.83 \mathrm{C}$ \\
\hline MNC04-789B-119-2-3-1 x MNC05-820B-240 & $38.94 \mathrm{~B}$ & $55.06 \mathrm{C}$ & $29.33 \mathrm{~B}$ & $15.67 \mathrm{C}$ & $9.12 \mathrm{C}$ & $20.33 \mathrm{~B}$ & $617.72 \mathrm{~B}$ \\
\hline IT82D-889 x IT82D-60 & $37.70 \mathrm{~A}$ & $54.17 \mathrm{C}$ & $22.17 \mathrm{C}$ & $19.62 \mathrm{~A}$ & $12.18 \mathrm{~A}$ & $12.83 \mathrm{E}$ & $541.17 \mathrm{C}$ \\
\hline IT82D-889 x AU94-MOB-816 & $36.36 \mathrm{~A}$ & $53.73 \mathrm{~B}$ & $31.28 \mathrm{~B}$ & $16.85 \mathrm{~B}$ & $10.82 \mathrm{~B}$ & $17.24 \mathrm{C}$ & $497.24 \mathrm{C}$ \\
\hline IT82D-60 x MNC04-789B-119-2-3-1 & $38.69 \mathrm{~B}$ & $55.06 \mathrm{C}$ & 29.46 B & $17.67 \mathrm{~B}$ & $10.43 \mathrm{~B}$ & $15.00 \mathrm{D}$ & $559.76 \mathrm{C}$ \\
\hline Parents means & 38.81 & 55.06 & 28.91 & 15.63 & 8.35 & 20.43 & 598.65 \\
\hline Crosses means & 37.82 & 54.17 & 38.57 & 16.15 & 10.63 & 16.88 & 583.94 \\
\hline General mean & 38.19 & 54.46 & 28.69 & 15.98 & 9.86 & 18.06 & 588.84 \\
\hline
\end{tabular}

${ }_{1}^{1}$ analysis carried out with data transformed into $\sqrt{\mathrm{x}}$

Means followed by the same letter belong to the same cluster by the Scott-Knott test at $5 \%$ probability.

A" IT82D-889 x IT82D-60 (12.18), AU94-MOB-816 x IT82D-60 (11.83), and IT82D-889 x MNC04-789B-119-2-3-1 (11.97). Five clusters were formed for W100G. Only the genotype MNC05-820B-240 was allocated in "Cluster A", with mean of 24.33g. The general mean (18.06 g) obtained for this trait was greater than the value obtained by Bertini et al. (2009), which was $15.84 \mathrm{~g}$. The most productive cross was IT82D-889 x MNC04-789B-119-2-3-1, with mean of $789.5 \mathrm{~kg} \mathrm{ha}^{-1}$.

\section{ACKNOWLEDGEMENTS}

The authors thank the staff of Embrapa Mid-North, Manuel Gonçalves da Silva, Agripino Ferreira and Paulo Sérgio Monteiro, for their valuable collaboration in the execution of the experiment. The authors also thank the Coordination for the Improvement of Higher Education Personnel (CAPES) for granting scholarship.

\section{REFERENCES}

Adeyanju AO and Ishiyaku MF (2007) Genetic study of earliness in cowpea (Vigna unguiculata L. Walp) under screen house condition. International Journal of Plant Breeding and Genetics1:34-37.

Bertini CHCM, Teofilo EM and Dias TC (2009) Divergência genética entre acessos de feijão-caupi do banco de germoplasma da UFC. Ciência Agronômica40: 99-105.

Cruz CD (2006) Programa Genes: Biometria. Editora UFV, Viçosa, 382p.

Cruz CD, Regazzi AJ and Carneiro PCS (2004) Modelos biométricos aplicados ao melhoramento genético. Editora UFV, Viçosa, 480p.

Cruz CD and Vencovsky R (1989) Comparação de alguns métodos de análise dialélica. Revista Brasileira de Genética12:425-438.

Freire Filho FR, Ribeiro VQ, Barreto PD and Santos AA (2005) Melhoramento genético. In Freire Filho, FR, Ribeiro VQ and Lima JAA (eds) Feijão-caupi: avanços tecnológicos. Embrapa Informação
Tecnológica, Brasília, p. 29-92.

Freire Filho FR, Ribeiro VQ, Rocha MM, Silva KJD, Nogueira MSR and Rodrigues EV (2011) Feijão-caupi: produção, melhoramento genético, avanços e desafios. Embrapa Informação Tecnológica, Brasília, 81p.

Pimentel Gomes F (2000) Curso de estatística experimental. Degaspari, Piracicaba, 477p.

Griffing B (1956) Aconcept of general and specific combining ability in relation to diallel crossing systems. Australian Journal of Biological Sciences9:463-493.

Hayman BI (1954) The theory and analysis of diallel crosses. Genetics39:789-809.

Lal S, Singh M and Pathak MM (1975) Combining ability in cowpea. Indian Journal of Genetics and Plant Breeding35:375-378.

Lorencetti C, Carvalho FIF, Benin G, Marchioro VS, Oliveira AC, Silva 
JAG, Hartwig I, Schmidt DAM and Valério IP (2005) Capacidade combinatória e heterose em cruzamento dialélico de aveia (Avena sativa L.). Revista Brasileira Agrociência11:143-148.

Oliveira Júnior A, Miranda GV and Cruz CD (1999) Predição de populações $\mathrm{F}_{3}$ a partir de dialelos desbalanceados. Pesquisa Agropecuária Brasileira34:781-787.

Padi FK (2007) Response to selection for grain yield and correlated response for grain size and earliness in cowpea based on early generation testing. Annals of Applied Biology152:361-368.

Rachie KO, Rawal KM and Franckowiak JD (1975) A rapid method for hand crossing cowpea. IITA, Ibadan, 5p. (IITA. Technical Bolletin, 2).

Ribeiro ND, Hoffmann Júnior L and Possebon SB (2004) Variabilidade genética para ciclo em feijão dos grupos preto e carioca. Revista Brasileira Agrociência10:19-29.

Santos A, Ceccon G, Correa AM, Durante LGY and Regis JAVB (2012) Análise genética e de desempenho de genótipos de feijão-caupi cultivados na transição do cerrado-pantanal. Cultivando o saber5: 87-102.

Silva FB, Ramalho MAP and Abreu AFB (2007) Seleção recorrente fenotípica para florescimento precoce de feijoeiro carioca. Pesquisa
Agropecuária Brasileira42:1437-1442.

Silva MP, Amaral Júnior AT, Rodrigues R, Daher RF, Leal NR and Schuelter AR (2004) Análise dialélica da capacidade combinatória em feijão de vagem. Horticultura Brasileira22:277-280.

Simone M, Failde V, Garcia S and Panadero PC (1992) Adaptación de variedades y líneas de judias secas (Phaseolus vulgaris L.) a la recolección mecanica directa. INTA, Salta:, $5 \mathrm{p}$.

Sprague GF and Tatum LA (1942) General vs. specific combining ability in single crosses of corn. Journal of the American Society of Agronomic 34: 923-932.

Teixeira NJP, Machado CF, Freire Filho FR, Rocha MM and Gomes RLF (2007) Produção, componentes de produção e suas inter-relações em genótipos de feijão-caupi (Vigna unguiculata (L.) Walp.) de porte ereto. Ceres 54: 374-382.

Xavier GR, Martins LMV, Rumjanek NG and Freire Filho FR (2005) Variabilidade genética em acessos de caupi analisada por meio de marcadores RAPD. Pesquisa Agropecuária Brasileira40:353-359.

Zary KW and Miller Junior JC (1982) Comparisson of two methods of hand-crossing Vigna unguiculata (L.) Walp. HortScience17: 246-248. 